\title{
ANALISIS FAKTOR KESUKSESAN IMPLEMENTASI APLIKASI SISTEM KEUANGAN DESA (SISKEUDES) DENGAN MENGGUNAKAN MODEL KESUKSESAN SISTEM TEKNOLOGI INFORMASI DIPERBARUI OLEH DELONE DAN MCLEAN DI KABUPATEN GIANYAR
}

\author{
Gusi Putu Lestara Permana ${ }^{1}$, Ni Wayan Mudiyanti2* \\ ${ }^{1,2}$ Fakultas Ekonomi dan Bisnis, Universitas Pendidikan Nasional (Undiknas) Denpasar \\ *e-mail: lestarapermana@undiknas.ac.id
}

DiPublikasi: 01/07/2021

https://doi.org/10.22225/kr.13.1.2021.75-85

\begin{abstract}
The purpose of this research is to know the success of the Implementation SISKEUDES application by using the information Technology System Success Model that was update by DeLone and McLean in Gianyar Regency. The DeLone and McLean models used of 6 constructs namely System Quality, Informastion Quality, Service Quality, Used, User Satisfaction, and Net Benefits. Data collection techniques using a questionnaire. The sample in this research were 64 people including users of the SISKEUDES application in Gianyar Regency. The data collected by analysed using Partial Least Square (PLS). the analytical method used by evaluating the measurement model (outer model) and structural model (inner model).

Keywords: DeLone and McLean Information Success Models, SISKEUDES application, System Quality, Information Quality, Service Quality, Use, User Satisfaction, Net Benefits.

\section{Abstrak}

Tujuan penelitian ini adalah untuk mengetahui Kesuksesan Implementasi Aplikasi Sistem Keuangan Desa (SISKEUDES) dengan Menggunakan Model Kesuksesan Sistem Teknologi Informasi yang diperbarui oleh DeLone dan McLean di Kabupaten Gianyar. Model DeLone dan McLean yang digunakan dalam penelitian ini terdiri dari 6 konstruk yaitu Kualitas Sistem, Kualitas Informasi, Kualitas Layanan, Penggunaan, Kepuasan Pengguna, dan Manfaat Bersih. Teknik pengumpulan data menggunakan kuesioner. Sampel dalam penelitian ini sebanyak 64 orang yang termasuk pengguna dari aplikasi SISKEUDES di Kabupaten Gianyar. Data yang telah terkumpul dianalisis dengan menggunakan Partial Least Square (PLS). Metode analisis yang digunakan dengan mengevaluasi model pengukuran (outer model) dan model struktural (inner model).

Kata Kunci : Model Kesuksesan Implementasi Sistem DeLone and McLean, Aplikasi SISKEUDES, Kualitas Sistem, Kualitas Informasi, Kualitas Layanan, Penggunaan, Kepuasan Pengguna, Manfaat Bersih.
\end{abstract}

\section{PENDAHULUAN}

Memasuki era milenial saat ini perkembangan tekonologi sudah tidak dapat dipungkiri, penggunaan TI membuat proses pekerjaan menjadi lebih sederhana dan tidak hanya diterapkan dalam sektor bisnis, namun dalam sektor publik, TI diterapkan untuk membantu tata kelola pemerintahan yang sesuai dengan pertanggungjawaban dalam penyelenggaraan pemerintah. Salah satu sistem teknologi informasi akuntansi sektor publik yang dikembangkan oleh Kemendagri bersama BPKP adalah Aplikasi Sistem Keuangan Desa (SISKEUDES). Aplikasi ini dikembangkan untuk mempermudah proses pengelolaan keuangan desa. Hal ini sesuai dengan amanat UU No 6 Tahun 2014 tentang Desa, dimana Desa sudah diberikan kesempatan yang sangat besar untuk mengatur tata kelola pemerintahannya sendiri termasuk dalam pengelolaan keuangan dan pembangunan. Sumber penerimaan dana desa yang begitu besar dari pemerintah pusat/daerah harus dikelola secara akuntabilitas, transparansi dan bebas dari penyalahgunaan.

Dengan adanya pengelolaan keuangan desa yang teraplikasi dalam sistem keuangan desa (SISKEUDES) diharapkan penerapan yang baik, apabila aplikasi ini sudah diimplementasikan dengan benar sesuai ketentuan yang berlaku akan berpengaruh pada perkembangan pemerintah desa. 
Untuk dapat mewujudkan hal tersebut diperlukan peran dan tanggung jawab SDM yang memadai dalam mengoperasikan sistem tersebut, karena kesuksesan suatu sistem itu diterapkan tergantung pada kualitas sistem, kualitas informasi, kualitas layanan, penggunaan sistem itu sendiri, kepuasan yang didapatkan, dan manfaat apa yang diperoleh dalam penggunaan sistem tersebut.

Salah satu modelyang digunakan untuk mengukur kesuksesan suatu sistem adalah Model (DeLone \& McLean, 2003). Dalam model trsebut menyebutkan beberapa variabel yang saling mempengaruhi seperti kualitas sistem, kualitas informasi, dan kualitas layanan berpengaruh terhadap penggunaan dan kepuasan pengguna, penggunaan dan kepuasan pengguna berpengaruh terhadap manfaat-manfaat bersih. Penelitian tersebut didukung oleh penelitian dari (Wahyuni, 2011), dalam penelitiannya mengembangkan 9 hipotesis, setelah dilakukan pengujian terhadap 9 hipotesis tersebut secara umum dapat dikatakan

\section{TINJAUAN PUSTAKA}

DeLone and McLean Model

Pada tahun 1992 Delone dan McLean mulai memperkenalkan Model Kesuksesan Sistem Informasi untuk pertama kalinya. Model ini menjelaskan bahwa pengukuran kesuksesan sistem informasi dikategorikan dalam 6 kategori yaitu kualitas sistem, kualitas informasi, penggunaan, kepuasan pengguna, dampak individu, dan dampak organisasional. Namun, pada tahun 2003 D\&M menyempurnakan model IS Success mereka dengan menambahkan variabel kualitas layanan, dan menggabungkan dampak individu serta dampak organisasional menjadi manfaat bersih. Penyempurnaan model D\&M (2003) ini memiliki 3 komponen yaitu:

1. Pembuatan sistem dinilai dengan kualitas sistem, kualitas informasi, dan kualitas layanan.

1. Penggunaan sistem dinilai dengan penggunaan dan kepuasan pengguna.

2. Dampak dari penggunaan sistem dinilai dari manfaat besih.

\section{Kualitas Sistem}

Kualitas sistem dapat mengukur karakteristik dalam sistem informasi itu sendiri, semakin baik kualitas sistem maka akan menghasilkan informasi yang berkualitas bagi kebutuhan pengguna.

\section{Kualitas Informasi}

bahwa model kesuksesan sistem informasi DeLone dan McLean terbukti secara signifikan dalam penelitiannya. Namun, hasil yang berbeda dari penelitian yang dilakukan oleh (Khairrunnisa \& Yunanto, 2017). Dari hasil penelitiannya dinyatakan bahwa kualitas sistem dan kualitas informasi tidak berpengaruh trhadap kesuksesan implementasi $e$-village budgeting .

Berdasarkan uraian latar belakang dan adanya perbedaan hasil penelitian dari (Wahyuni, 2011) dengan (Khairrunnisa \& Yunanto, 2017) dalam kesempatan kali ini peneliti ingin meneliti tentang kesuksesan implementasi Sistem Keuangan Desa (SISKEUDES) di Kabupaten Gianyar mengangkat Judul "Analisis Faktor Kesuksesan Implementasi Aplikasi Sistem Keuangan Desa (SISKEUDES) dengan Menggunakan Model Kesuksesan Sistem Teknologi Informasi diperbarui oleh DeLone dan McLean di Kabupaten Gianyar".

Kualitas informasi merujuk pada output dari sistem informasi. kualitas informasi itu berfokus pada informasi yang dihasilkan oleh suatu sistem.

\section{Kualitas Layanan}

Kualitas layanan artinya kualitas dukungan yang diterima pengguna dari sistem yang sedang dioperasikan.

\section{Penggunaan}

Penggunaan artinya suatu cara dimana pengguna memanfaatkan kemampuan dari suatu sistem informasi.

\section{Kepuasan Pengguna}

Keseluruhan evaluasi dari pengalaman pengguna dalam menggunakan sistem informasi, jika si pengguna merasa puas, maka akan mempengaruhi niat untuk menggunakan sistem itu kembali.

\section{Manfaat Bersih}

Manfaat bersih merupakan dampak yang diterima pengguna dalam menggunakan suatu sistem terhadap kualitas kinerja pengguna baik secara individual maupun organisasional.

Sejarah, Pengertian, dan Penggunaan Aplikasi Sistem Keuangan Desa (SISKEUDES)

Aplikasi Sistem Keuangan Desa atau yang lebih dikenal dengan singkatan SISKEUDES merupakan aplikasi sistem tata kelola keuangan desa yang dikembangkan oleh Badan Pemeriksa Keuangan dan Pembangunan (BPKP) pada tahun 2015 yang

Jurnal KRISNA: Kumpulan Riset Akuntansi Volume 11, Nomor 22020 CC-BY-SA 4.0 License

Page 76 
diperuntukkan dalam membantu pengelolaan keuangan di desa. Penggunaan aplikasi ini harus mendapat persetujuan dari BPKP selaku pengembang aplikasi. Pemerintah Daerah (PEMDA) mengajukan permohonan untuk penggunaan aplikasi kepada Perwakilan BPKP di daerah setempat. Pegajuan aplikasi ini agar dikoordinasikan oleh PEMDA sehingga dapat diterapkan pada semua desa yang ada di pemerintah daerah yang mengajukan permohonan tersebut. Persetujuan penggunaan aplikasi dilakukan dengan memberikan kode valiidasi yang sudah dikeluarkan secara resmi oleh BPKP. Aplikasi sistem keuangan desa terbaru tahun 2019 V2.0 R2.0.0 ini merupakan pengembangan yang sudah mengacu pada Peraturan Menteri Dalam Negeri (Permendagri)No 20 Tahun 2018.

\section{Pengelolaan Keuangan Desa}

Pengelolaan keuangan desa merupakan suatu bentuk tahap atau proses dalam mengelola keuangan desa yang terdiri dari 5 tahap yaitu :

1. Perencanaan

2. Pelaksanaan

3. Penatausahaan

4. Pelaporan

5. Pertanggungjawaban

\section{Hipotesis Peneitian}

$\mathrm{H}_{\mathrm{a}}$ : $\quad$ Kualitas sistem berpengaruh positif terhadap penggunaan aplikasi Sistem Keuangan Desa (SISKEUDES)

$\mathrm{H} 1_{b}$ : Kualitas sistem berpengaruh positif terhadap kepuasan pengguna aplikasi Sistem Keuangan Desa (SISKEUDES)

$\mathrm{H}_{2}$ a Kualitas informasi berpengaruh positif terhadap penggunaan aplikasi Sistem Keuangan Desa (SISKEUDES)

$\mathrm{H} 2_{\mathrm{b}}$ : $\quad$ Kualitas informasi berpengaruh positif terhadap kepuasan pengguna aplikasi Sistem Keuangan Desa (SISKEUDES)

$\mathrm{H} 3_{\mathrm{a}}$ : Kualitas Layanan berpengaruh positif terhadap Penggunaan Aplikasi Sistem Keuangan Desa (SISKEUDES)

$\mathrm{H} 3_{\mathrm{b}}$ : Kualitas Layanan berpengaruh positif terhadap Kepuasan Pengguna Aplikasi Sistem Keuangan Desa (SISKEUDES)

H4 : Penggunaan berpengaruh positif terhadap Kepuasan Pengguna Aplikasi Sistem Keuangan Desa (SISKEUDES)

$\mathrm{H} 5_{\mathrm{a}}$ : Penggunaan berpengaruh positif terhadap Manfaat Bersih Aplikasi Sistem Keuangan Desa (SISKEUDES)

$\mathrm{H} 5_{\mathrm{b}}$ : Kepuasan Pengguna berpengaruh positif terhadap Manfaat Bersih Aplikasi Sistem Keuangan Desa (SISKEUDES)

\section{METODE PENELITIAN}

Penelitian ini dilakukan di Kabupaten Gianyar. Kabupaten Gianyar terdiri dari 7 (Tujuh) Kecamatan, 6 (Enam) Kelurahan dan 64 (Enam Puluh Empat) Desa. Jumlah populasi sebanyak 64 orang. Dan sampel yang digunakan adalah sampel jenuh, dimana seluruh populasi dijadikan sampel. Sehingga sampel yanng digunakan dalam penelitian ini adalah 64 orang. Jenis data yang digunakan dalam penelitian ini adalah data kuantitatif. Data yang diperoleh seperti, hasil jawaban responden pada kuesioner yang telah diberikan kepada

\section{HASIL DAN PEMBAHASAN Karakteristik Responden}

Hasil dari penyebaran kuesioner yang diperoleh dari 64 responden berdasarkan usia yang lebih mendominasi adalah di usia 20-30 tahun sebanyak 41 orang dengan presentase $64,1 \%$, usia $30-40$ tahun sebanyak 22 orang dengan presentase $34,3 \%$, pengguna aplikasi SISKEUDES di Desa Kabupaten Gianyar dengan skala likert menggunakan 5 (lima) poin skala. Dan sumber data yang diperlukan ini dihasilkan dari sumber data primer. Penelitian ini menggunakn Instrumen Penelitian Structural Equation Modeling (SEM) dan pengujiannya menggunakan Partial Least Square (PLS). Evaluasi model PLS dilakukan dengan mengevaluasi model pengukuran (outer model) dan model structural (inner model).

usia 40-50 tahun sebanyak 1 orang dengan presentase $1,6 \%$. Jika dilihat berdasarkan jenis kelamin yang lebih mendominasi adalah perempuan sebanyak 43 orang dengan resentase $67,2 \%$ dan laki-laki sebanyak 21 orang dengan presentase $32,8 \%$. Dan yang terakhir berdasarkan pendidikan 
terakhir yang mendominasi yaitu di tingkat S1 sebanyak 38 orang dengan presentase $59,4 \%$, selanjutnya di tingkat SMA sebanyak 15 orang dengan presentase $23,4 \%$, Diploma sebanyak 10 orang dengan presentase $15,6 \%$, dan S2 sebanyak 1 orang dengan presentase $1,6 \%$
Hasil Evaluasi Model Pengukuran (outer model)

Outer model mengukur konstruk-konstruk beserta indikator-indikatornya. Dalam outer model menguji validitas dan reliabilitas.

Tabel 1.

Parameter Uji Validitas dalam Model Pengukuran PLS

\begin{tabular}{|c|c|c|}
\hline Uji Validitas & Parameter & Rule of Thumbs \\
\hline Konvergen & Faktor Loading & Lebih dari 0,7 \\
\hline & $\begin{array}{c}\text { Average variance extracte } \\
\text { (AVE) }\end{array}$ & Lebih dari 0,5 \\
\hline \multirow{2}{*}{ Diskriminan } & Communality & Lebih dari 0,5 \\
\hline & $\begin{array}{c}\text { Akar AVE dan Korelasi } \\
\text { variabel laten }\end{array}$ & $\begin{array}{c}\text { Akar AVE }>\text { Korelasi varia } \\
\text { laten }\end{array}$ \\
\hline & Cross Loading & Leih dari 0,7 dalam satu \\
& & variabel \\
\hline
\end{tabular}

Validitas Diskriminan dengan Menggunakan Cross Loading

\begin{tabular}{|c|c|c|c|c|c|c|}
\hline & $\begin{array}{l}\text { Kepuasan } \\
\text { Pengguna }\end{array}$ & $\begin{array}{l}\text { Kualitas } \\
\text { Informasi }\end{array}$ & $\begin{array}{l}\text { Kualitas } \\
\text { Layanan }\end{array}$ & $\begin{array}{l}\text { Kualitas } \\
\text { Sistem }\end{array}$ & $\begin{array}{l}\text { Manfaat } \\
\text { Bersih }\end{array}$ & Penggunaan \\
\hline H1.1 & 0.832 & 0.818 & 0.599 & 0.942 & 0.825 & 0.848 \\
\hline H1.2 & 0.754 & 0.730 & 0.583 & 0.944 & 0.798 & 0.772 \\
\hline H1.3 & 0.678 & 0.661 & 0.585 & 0.900 & 0.792 & 0.690 \\
\hline H1.4 & 0.739 & 0.704 & 0.578 & 0.920 & 0.799 & 0.686 \\
\hline H1.5 & 0.743 & 0.714 & 0.644 & 0.910 & 0.775 & 0.640 \\
\hline H2.1 & 0.725 & 0.886 & 0.480 & 0.714 & 0.772 & 0.683 \\
\hline H2.2 & 0.770 & 0.910 & 0.522 & 0.698 & 0.788 & 0.748 \\
\hline H2.3 & 0.680 & 0.862 & 0.423 & 0.600 & 0.657 & 0.619 \\
\hline H2.4 & 0.704 & 0.842 & 0.449 & 0.671 & 0.650 & 0.601 \\
\hline H2.5 & 0.684 & 0.863 & 0.440 & 0.672 & 0.699 & 0.630 \\
\hline H2.6 & 0.800 & 0.924 & 0.509 & 0.778 & 0.844 & 0.743 \\
\hline H2.7 & 0.690 & 0.810 & 0.423 & 0.667 & 0.699 & 0.608 \\
\hline H3.1 & 0.468 & 0.498 & 0.909 & 0.600 & 0.597 & 0.557 \\
\hline H3.2 & 0.575 & 0.482 & 0.952 & 0.582 & 0.545 & 0.670 \\
\hline H3.3 & 0.593 & 0.521 & 0.946 & 0.635 & 0.591 & 0.623 \\
\hline H4.1 & 0.791 & 0.748 & 0.628 & 0.759 & 0.768 & 0.975 \\
\hline H4.2 & 0.785 & 0.738 & 0.662 & 0.786 & 0.769 & 0.975 \\
\hline H5.1 & 0.896 & 0.718 & 0.462 & 0.715 & 0.706 & 0.642 \\
\hline H5.2 & 0.921 & 0.777 & 0.501 & 0.745 & 0.727 & 0.782 \\
\hline H5.3 & 0.934 & 0.784 & 0.637 & 0.777 & 0.810 & 0.789 \\
\hline H6.1 & 0.832 & 0.827 & 0.552 & 0.793 & 0.948 & 0.704 \\
\hline H6.2 & 0.714 & 0.764 & 0.613 & 0.843 & 0.945 & 0.789 \\
\hline
\end{tabular}

Uji Validitas diskriminan dinilai berdasarkan cross loading pengukuran dengan konstruknya. Berdasarkan tabel di atas dapat diketahui bahwa masing - masing variabel lebih besar dari 0,7 Dengan demikian dapat dinyatakan bahwa data dalam penelitian ini adalah valid. 
Validitas Diskriminan dengan AVE

\begin{tabular}{|l|c|}
\hline & \begin{tabular}{c} 
Average Variance Extracted (AVE) \\
\hline \multicolumn{1}{|c|}{ Kepuasan Pengguna }
\end{tabular} \\
\hline Kualitas Informasi & $\mathbf{0 . 8 4 1}$ \\
\hline Kualitas Layanan & $\mathbf{0 . 7 6 0}$ \\
\hline Kualitas Sistem & $\mathbf{0 . 8 7 7}$ \\
\hline Manfaat Bersih & $\mathbf{0 . 8 5 3}$ \\
\hline Penggunaan & $\mathbf{0 . 8 9 6}$ \\
\hline
\end{tabular}

Model lain untuk menilai discriminate validity adalah membandingkan akar kuadrat dari average variance extracted (AVE) untuk setiap variabel dengan korelasi antar variabel dengan variabel lainnya didalam model.Berdasrkan tabel validitas diskriminan dengan pengukuran AVE di atas dapat dilihat bahwa semua nilai average variance extracted (AVE) lebih dari 0.5. Dengan demikian dapat dinyatakan bahwa data dalam penelitian valid.

\section{Validitas Diskriminan Korelasi Variabel Laten}

\begin{tabular}{|c|c|c|c|c|c|c|}
\hline & $\begin{array}{l}\text { Kepuasan } \\
\text { Pengguna }\end{array}$ & $\begin{array}{l}\text { Kualitas } \\
\text { Informasi }\end{array}$ & $\begin{array}{l}\text { Kualitas } \\
\text { Layanan }\end{array}$ & $\begin{array}{l}\text { Kualitas } \\
\text { Sistem }\end{array}$ & $\begin{array}{l}\text { Manfaat } \\
\text { Bersih }\end{array}$ & Penggunaan \\
\hline Kepuasan Penggun & 0.917 & & & & & \\
\hline Kualitas Informasi & 0.830 & 0.872 & & & & \\
\hline Kualitas Layanan & 0.586 & 0.534 & 0.936 & & & \\
\hline Kualitas Sistem & 0.814 & 0.789 & 0.646 & 0.924 & & \\
\hline Manfaat Bersih & 0.818 & 0.841 & 0.615 & 0.864 & 0.946 & \\
\hline Penggunaan & 0.808 & 0.762 & 0.662 & 0.792 & 0.789 & 0.975 \\
\hline $\begin{array}{l}\text { Validitas Diskirimi } \\
\text { ngan prinsip bahwa pe } \\
\text { ng berbeda seharusny } \\
\text { i validitas diskriminan } \\
\text { ading peng } \\
\text { nstruknya.Berdasrkan } \\
\text { pat dilihat bahwa } \\
\text { lidity korelasi variab } \\
\text { asing variabel lebih } \\
\text { mikian dapat dinyat } \\
\text { nelitian valid. }\end{array}$ & $\begin{array}{l}\text { nan yaitu } \\
\text { ngukur-peng } \\
\text { a tidak berk } \\
\text { dinilai berc } \\
\text { ukuran } \\
\text { Tabel yang } \\
\text { semua nilai } \\
\text { el laten pa } \\
\text { besar dari } \\
\text { akan bahwa }\end{array}$ & $\begin{array}{l}\text { berhubungan } \\
\text { kur konstruk } \\
\text { relasi tinggi. } \\
\text { sarkan cross } \\
\text { dengan } \\
\text { rtera di atas } \\
\text { discriminant } \\
\text { masing - } \\
0,7 \text { Dengan } \\
\text { data dalam }\end{array}$ & $\begin{array}{l}\text { Com } \\
\text { U. } \\
\text { tingk } \\
\text { instr } \\
\text { atau } \\
\text { relia } \\
\text { relia } \\
\text { men } \\
\text { kons } \\
\text { digu } \\
\text { relia }\end{array}$ & $\begin{array}{l}\text { posite Reli } \\
\text { i reliabili } \\
\text { at konsist } \\
\text { amen penel } \\
\text { konstruk. } \\
\text { oilitas yait } \\
\text { bility. Cro } \\
\text { gukur bata } \\
\text { truk, se } \\
\text { takan untul } \\
\text { oilitas suatu }\end{array}$ & $\begin{array}{l}\text { ability } \\
\text { as adalah } \\
\text { insi dan } \\
\text { itian d alan } \\
\text { Menggunal } \\
\text { cronbach } \\
\text { nbach's } \\
\text { s bawah } \\
\text { langkan } \\
\text { menguku } \\
\text { konstruk. }\end{array}$ & $\begin{array}{l}\text { menunjukka } \\
\text { stabilitas alat } \\
\text { n mengukur su } \\
\text { kan dua metod } \\
\text { 's alpha dan } \\
\text { alpha digunak } \\
\text { nilai reliabil } \\
\text { composite } \\
\text { r nilai sesungg }\end{array}$ \\
\hline
\end{tabular}




\section{Hasil Uji Reliabilitas Cronbach's alpha}

\begin{tabular}{|c|}
\hline Kepuasan Pengguna \\
Kualitas Informasi \\
Kualitas Layanan \\
Kualitas Sistem \\
Manfaat Bersih \\
Penggunaan
\end{tabular}

Berdasrkan Tabel di atas dapat dilihat bahwa semua nilai Cronbach's alpha pada masing-masing variabel lebih besar dari 0,7. Dengan demikian
Cronbach's Alpha

\begin{tabular}{|c|}
\hline 0.905 \\
\hline 0.947 \\
\hline 0.930 \\
\hline 0.957 \\
\hline 0.884 \\
\hline 0.948 \\
\hline
\end{tabular}

dapat dinyatakan bahwa data dalam penelitian reliabel

\section{Hasil Uji Reliabilitas Composite reliability}

\begin{tabular}{|l|c|}
\hline & Composite Reliability \\
\hline Kepuasan Pengguna & $\mathbf{0 . 9 4 1}$ \\
\hline Kualitas Informasi & $\mathbf{0 . 9 5 7}$ \\
\hline Kualitas Layanan & $\mathbf{0 . 9 5 5}$ \\
\hline Kualitas Sistem & $\mathbf{0 . 9 6 7}$ \\
\hline Manfaat Bersih & $\mathbf{0 . 9 4 5}$ \\
\hline Penggunaan & $\mathbf{0 . 9 7 5}$ \\
\hline
\end{tabular}

Berdasarkan tabel di atas dapat dilihat bahwa semua nilai Composite reliability pada masing-masing variabel lebih besar dari 0,7. Dengan demikian dapat dinyatakan bahwa data dalam penelitian reliabel.

Validitas Konvergen

\begin{tabular}{|c|c|c|c|c|c|c|}
\hline & $\begin{array}{l}\text { Kepuasa } \\
\text { Penggun }\end{array}$ & $\begin{array}{l}\text { Kualitas } \\
\text { Informa }\end{array}$ & $\begin{array}{l}\text { Kualita } \\
\text { Layana }\end{array}$ & $\begin{array}{l}\text { Kualita } \\
\text { Sistem }\end{array}$ & $\begin{array}{l}\text { Manfa: } \\
\text { Bersih }\end{array}$ & Penggunaa \\
\hline H1.1 & & & & 0.942 & & \\
\hline H1.A & & & & 0.94 & & \\
\hline H1.: & & & & 0.900 & & \\
\hline H1.6 & & & & 0.921 & & \\
\hline H1. & & & & 0.910 & & \\
\hline H2.1 & & 0.886 & & & & \\
\hline H2. & & 0.910 & & & & \\
\hline
\end{tabular}




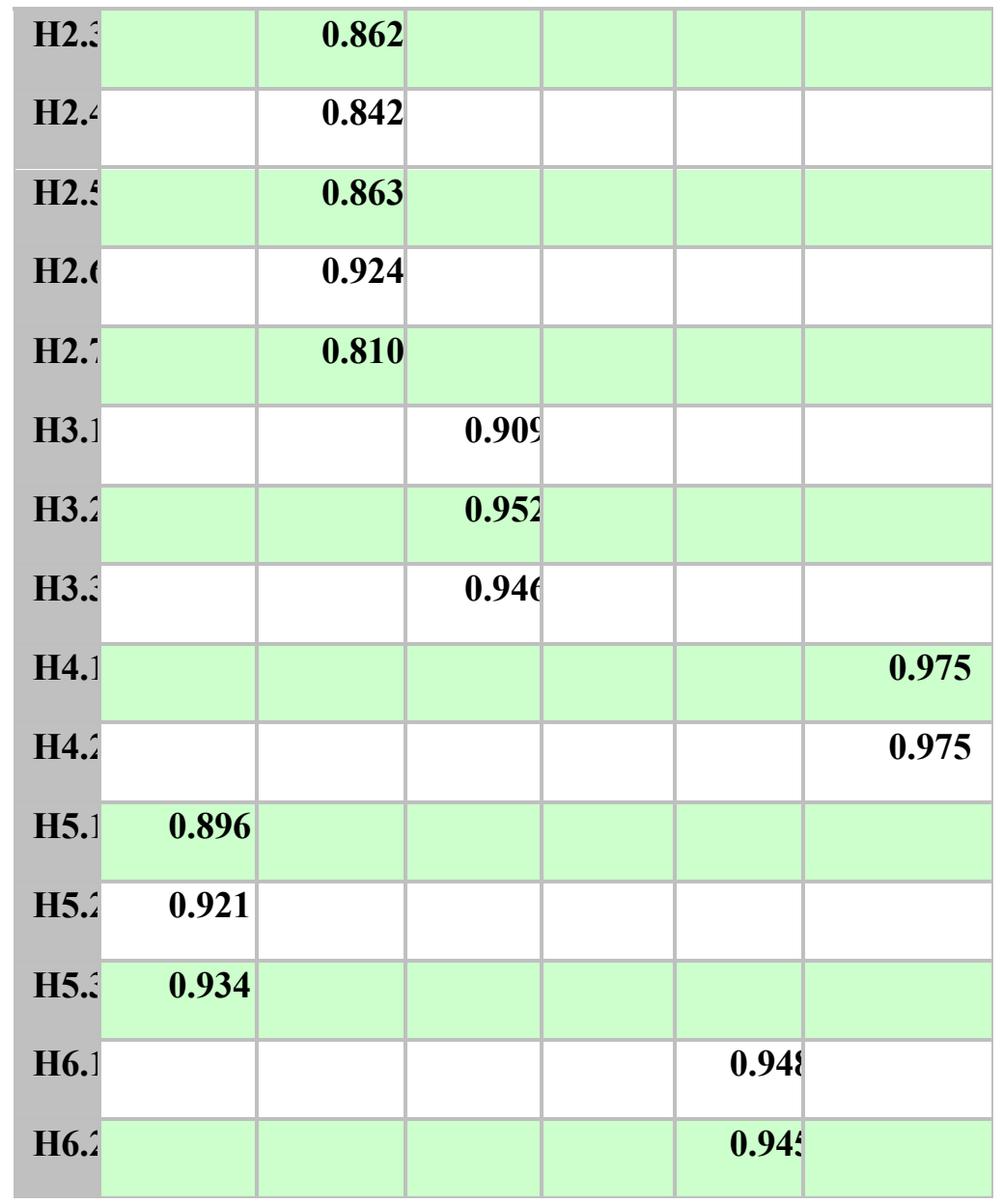

Validitas konvergen yang berhubungan dengan prinsip bahwa pengukur dari suatu konstruk harus berkorelasi tinggi. Uji validitas konvergen dalam PLS dengan menggunakan indikator reflektif dinilai berdasarkan loading factor (korelasi antara skor item/skor komponen dengan skor konstruk) indikator-indikator yang mengukur konstruk tersebut. Berdasarkan Tabel di atas dapat dilihat bahwa semua nilai pada uji validitas convergent lebih besar dari 0,7. Dengan demikian dapat dinyatakan bahwa data dalam penelitian valid.

Hasil Evaluasi Model Struktural (inner model)

Inner model mengukur hubungan antara satu konstruk dengan konstruk lainnya di dalam satu model.

\begin{tabular}{|l|c|c|}
\hline \multicolumn{1}{c}{ R-square } \\
\hline & \multicolumn{1}{c}{ R Square } & R Square Adjustec \\
\hline Kepuasan Pengguna & 0.784 & 0.769 \\
\hline Manfaat Bersih & 0.716 & 0.706 \\
\hline Penggunaan & 0.712 & 0.698 \\
\hline
\end{tabular}


Berdasarkan Tabel di atas diketahui bahwa nilai Rmanfaat bersih sebesar 0,716 termasuk moderat yang square untuk variabel kualitas sistem, kualitasmenunjukkan memiliki besar pengaruh $0,716 \times 100 \%=$ informasi, dan kualitas layanan terhadap kepuasan $71,6 \%$. Nilai R-square untuk variable kualitas sistem, pengguna sebesar 0,784 termasuk baik yangkualitas informasi, dan kualitas layanan terhadap menunjukkan memiliki besar pengaruh $0,784 \times 100 \%$ penggunaan sebesar 0,712 termasuk moderat yang $78,4 \%$. Nilai R-square untuk variable kualiitas sistemmenunjukkan memiliki besar pengaruh $0,712 \times 100 \%=$ kualits informasi, dan kualitas layanan terhadap $1,2 \%$.

\section{Pengujian Hpotesis}

\begin{tabular}{|c|c|c|c|c|}
\hline & $\begin{array}{r}\text { Original } \\
\text { Sample (O }\end{array}$ & Sample Mean ( & $\begin{array}{l}\text { Standard } \\
\text { Deviation } \\
\text { (STDEV) }\end{array}$ & $\begin{array}{r}\text { T Statistics } \\
(|\mathrm{O} / \mathrm{STDEV}|\end{array}$ \\
\hline \multirow{3}{*}{$\begin{array}{l}\text { Kepuasan Pengguna -> } \\
\text { Manfaat Bersih } \\
\text { Kualitas Informasi -> } \\
\text { Kepuasan Pengguna } \\
\text { Kualitas Informasi -> } \\
\text { Penoounaan }\end{array}$} & 0.520 & 0.536 & 0.148 & 3.515 \\
\hline & 0.391 & 0.386 & 0.135 & 2.892 \\
\hline & 0.348 & 0.347 & 0.182 & 1.913 \\
\hline $\begin{array}{l}\text { Kualitas Layanan -> } \\
\text { Kepuasan Pengguna }\end{array}$ & 0.013 & 0.014 & 0.083 & 0.154 \\
\hline $\begin{array}{l}\text { Kualitas Layanan -> } \\
\text { Penggunaan }\end{array}$ & 0.243 & 0.231 & 0.098 & 2.485 \\
\hline $\begin{array}{l}\text { Kualitas Sistem -> } \\
\text { Kepuasan Pengguna }\end{array}$ & 0.269 & 0.279 & 0.141 & 1.909 \\
\hline $\begin{array}{l}\text { Kualitas Sistem -> } \\
\text { Penggunaan }\end{array}$ & 0.361 & 0.364 & 0.176 & 2.052 \\
\hline $\begin{array}{l}\text { Penggunaan }->\text { Kepuasan } \\
\text { Pengguna }\end{array}$ & 0.288 & 0.276 & 0.114 & 2.524 \\
\hline $\begin{array}{l}\text { Penggunaan -> Manfaat } \\
\text { Bersih }\end{array}$ & 0.368 & 0.345 & 0.162 & 2.275 \\
\hline
\end{tabular}

\begin{tabular}{|r|c|c|}
\hline Hipotesis & Efek & T-statistics \\
\hline $\mathrm{H} 1_{\mathrm{a}}$ & $\mathrm{KS}>\mathrm{P}$ & $2,052>1,64$ \\
\hline $\mathrm{H} 1_{\mathrm{b}}$ & $\mathrm{KS}>\mathrm{KP}$ & $1,909>1,64$ \\
\hline $\mathrm{H} 2_{\mathrm{a}}$ & $\mathrm{KI}>\mathrm{P}$ & $1,913>1,64$ \\
\hline $\mathrm{H} 2_{\mathrm{b}}$ & $\mathrm{KI}>\mathrm{KP}$ & $2,982>1,64$ \\
\hline $\mathrm{H} 3_{\mathrm{a}}$ & $\mathrm{KL}>\mathrm{P}$ & $2,485>1,64$ \\
\hline $\mathrm{H} 3_{\mathrm{b}}$ & $\mathrm{KL}>\mathrm{KP}$ & $0,154<1,64$ \\
\hline $\mathrm{H} 4$ & $\mathrm{P}>\mathrm{KP}$ & $2,524>1,64$ \\
\hline $\mathrm{H} 5_{\mathrm{a}}$ & $\mathrm{P}>\mathrm{MB}$ & $2,275>1,64$ \\
\hline $\mathrm{H} 5_{\mathrm{b}}$ & $\mathrm{KP}>\mathrm{MB}$ & $3,515>1,64$ \\
\hline
\end{tabular}

Pembahasan Hasil Penelitian

Pengaruh Kualitas Sistem Terhadap Penggunaan

Berdasarkan hasil analisis data didapat hasil nilai T-statistics dari variabel Kualitas Sistem terhadap Penggunaan sebesar 2,052 lebih besar dari t-tabel 1,64 (2,052 > 1,64) dan Original Sample (O) sebesar positif 0,361 maka dapat ditarik
Original Sampe Hasil Uji Hipotes

$0,361 \quad$ Diterima

$0,269 \quad$ Diterima

$0,348 \quad$ Diterima

$0,391 \quad$ Diterima

$0,243 \quad$ Diterima

$0,013 \quad$ Ditolak

$0,288 \quad$ Diterima

$0,368 \quad$ Diterima

$0,520 \quad$ Diterima

kesimpulannya bahwa kualitas sistem berpengaruh positif terhadap penggunaan. Dari hasil penelitian ini serupa dengan hasil penelitian yang dlakukan oleh Hudin dan Riana (2016) menyatakan bahwa kualitas sitem berpengaruh signifikan terhadap Penggunaan.

Pengaruh Kualitas Sistem Terhadap Kepuasan Pengguna 
Berdasarkan hasil analisis data didapat hasil nilai T-statistics dari variabel Kualitas Sistem terhadap Kepuasan Pengguna sebesar 1,909 lebih besar dari t-tabel 1,64 $(1,909>1,64)$ dan Original Sample (O) sebesar positif 0,269 maka dapat disimpulkan bahwa kualitas sistem berpengaruh positif terhadap kepuasan pengguna. Menurut hasil penelitian (Rio Jumardi, Eko Nugroho, 2015) menunjukkan adanya pengaruh yang signifikan dari kualitas sistem terhadap kepuasan pengguna (user satisfaction). Peneliti lainnya yang menemukan hasil serupa adalah penelitian yang dilakukan oleh (Wahyuni, 2011).

\section{Pengaruh Kualitas Informasi Terhadap Penggunaan}

Sesuai dengan hasil analisis data maka didapat hasil yaitu nilai T-statistics dari variabel Kualitas Informasi terhadap Penggunaan sebesar 1,913 lebih besar dari t-tabel 1,64 $(1,913>1,64)$ dan Original Sample (O) sebesar positif 0,348 maka dapat ditarik kesimpulannya bahwa kualitas informasi berpengaruh positif terhadap penggunaan. Hal ini sejalan dengan hasil penelitian Subchan et. All (2012) yang menyatakan Kualitas Informasi yang disediakan portal akademik (SIAM) mempunyai pengaruh yang signifikan secara langsung terhadap Pengguna sistem.

\section{Pengaruh Kualitas Informasi Terhadap Kepuasan Pengguna}

Hasil analisis data menunjukan bahwa nilai T-statistics dari variabel Kualitas Informasi terhadap Kepuasan Pengguna sebesar 2,892 lebih besar dari t-tabel 1,64 $(2,982>1,64)$ dan Original Sample (O) sebesar positif 0,391, maka dapat ditarik kesimpulannya bahwa kualitas informasi berpengaruh positif terhadap kepuasan pengguna. Semakin tiinggi kualitas informasi yang dihasilkan suatu sistem informasi, akan semakin meningkatkan kepuasan pengguna (DeLone \& McLean, 2003).

\section{Pengaruh Kualitas Layanan Terhadap Penggunaan}

Berdasarkan hasil analisis data didapat hasil nilai T-statistics dari variabel Kualitas Layanan terhadap Penggunaan sebesar 2,485 lebih besar dari t-tabel 1,64 (2,485 > 1,64) dan Original Sample (O) sebesar positif 0,243, maka dapat disimpulkan bahwa kualitas layanan berpengaruh positif terhadap penggunaan. Dalam penelitian Purwanto dan Suharno (2007) menyatakan bahwa kualitas layanan berpengaruh signifikan terhadap penggunaan dan terdapat hubungan yang searah antar kualiitas layanan dengan penggunaan, hubugn yang dimaksud yaitu semakin tinggi kualitas layanan yang disediakan sistem maka akan semakin tinggi pula tingkat pengguna sistem itu sendiri.

\section{Pengaruh Kualitas Layanan Terhadap Kepuasan Pengguna}

Berdasarkan hasil analisis data didapat hasil nilai $\mathrm{T}$-statistics dari variabel Kualitas Layanan terhadap Kepuasan Pengguna sebesar 0,154 lebih kecil dari t-tabel 1,64 $(0,154<1,64)$ dan Original Sample (O) sebesar positif 0,013 maka dapat disimpulkan bahwa kualitas layanan tidak berpengaruh positif terhadap kepuasan pengguna. Jika dilihat dari pernyataan yang tercantum di kuesioner menunjukkan bahwa indikator tanggap, jaminan, dan empati tidak dapat memberikan keyakinan responden dalam menjawab pernyataan tersebut. Dalam kenyataan sebenarnya operator aplikasi SISKEUDES ini lebih banyak melakukan sharing melalui online dengan pihak admin. Selain hal tersebut, Karena aplikasi ini bersifat keharusan (mandatory) maka bagi pihak operator atau pengguna dalam menjalankan tugas dan tanggungjawabnya harus bergantung dengan aplikasi SISKEUDES dala keadaan apapun.

Penelitian yang dilakukan oleh (Rio Jumardi, Eko Nugroho, 2015) menunjukkan bahwa tidak adanya pengaruh yang signifikan dari variabel Kualitas Layanan terhadap Kepuasan Pengguna. Selain itu, penelitian dari Jessica Ordelia Kristanto (2018) menyatakan bahwa Kualitas Layanan tidak berpengaruh terhadap Kepuasan Pelanggan karena ada beberapa sumber terbuktinya hipotesis penelitin tersebut tidak memiliki pengaruh yaitu landasan teori, sampel, alat pengambilan data, rancangan penelitian, perhitungan-perhitungan, dan variabelvariabel luaran.

\section{Pengaruh PenggunaanTerhadap Kepuasan Pengguna}

Berdasarkan hasil analisis data didapat hasil nilai T-statistics dari variabel Penggunaan terhadap Kepuasan Pengguna sebesar 2,524 lebih besar dari t-tabel 1,64 (2,524 > 1,64) dan Original Sample (O) sebesar positif 0,288 maka dapat ditarik kesimpulannya bahwa penggunaan berpengaruh positif terhadap kepuasan pengguna. Penelitian yang dilakukan oleh (Khairrunnisa \& Yunanto, 2017) menyatakan bahwa adanya pengaruh yang signifikan terhadap kesuksesan implementasi $E$ Village Budgeting. 


\section{Pengaruh Penggunaan Terhadap Manfaat Bersih}

Berdasarkan hasil analisis data didapat hasil nilai T-statistics dari variabel Penggunaan terhadap Manfaat Bersih sebesar 2,275 lebih besar dari ttabel 1,64 $(2,275>1,64)$ dan Original Sample $(\mathrm{O})$ sebesar positif 0,368 maka dapat ditarik kesimpulannya bahwa penggunaan berpengaruh positif terhadap manfaat bersih. Hal ini sejalan dengan penelitian yang dilakukan oleh Hudin dan Riana (2016), yang menyatakan bahwa Penggunaan berpengaruh terhadap Manfaat Bersih.

\section{KESIMPULAN DAN SARAN}

Berdasarkan hasil analisis penelitian dan pembahasan diatas maka kesimpulan dari penelitian ini adalah Kualitas Sistem berpengaruh positif terhadap Penggunaan, hal ini berarti apabila jika Kualitas Sistem semakin meningkat maka Penggunaan semakin meningkat pula. Kualitas Sistem berpengaruh posiitif terhadap Kepuasan Pengguna. Kualitas Informasi berpengaruh positiif terhadap Penggunaan. Kualitas Inforrmasi berpengaruh positiif terhdap Kepuasan Pengguna. Kualitas Layanan berpengaruh positiif terhadp Penggunaan. Kualitas Layanan tidak berpengaruh positif trhadap Kepuasan Pengguna Aplikasi Sistem Keuangan Desa (SISKEUDES) di Kabupaten Gianyar. Hal ini berarti Kualitas Layanan tidak mempengaruhi peningkatan maupun penurunan dari

\section{DAFTAR PUSTAKA}

BPKP. (2018a). Aplikasi Sistem Keuangan Desa (SISKEUDES) Dalam Rangka Mengawal Prioritas Pemerintah (Nawa Cita). Retrieved September 3, 2018, from www.bpkp.go.id/sakd/konten/2448/Leaflet-SImdaDesa.bpkp

BPKP. (2015). Petunjuk pelaksanaan bimbingan dan konsultasi pengelolaan keuangan desa. Juklak Bimkon Pengelolaan Keuangan Desa.

Dewi, L. N. W., \& Rini, I. S. I. G. A. (2018). Pengaruh Pengawasan Keuangan, Sumber Daya Manusia, Teknologi Informasi, dan Pengendalian Intern Terhadap Nilai Informasi Pelaporan Keuangan Pemerintah Daerah Kabupaten Tabanan. Krisna, Vol. 10(1), 57. Retrieved from http://ejournal.warmadewa.ac.id/index.php/krisna

Jogiyanto, H. (2007). Model Kesuksesan Sistem Teknologi Informasi. Yogyakarta: Andi Publisher.

Jogiyanto,. dan Abdillah, W. (2016). Konsep dan Aplikasi PLS (Partial Least Square) untuk Penelitian Empiris. BPFE Yoovakarta (BPEE Ed Yoovakarta

\section{Pengaruh Kepuasan PenggunaTerhadap Manfaat Bersih}

Hasil analisis data menunjukan bahwa nilai T-statistics dari variabel Kepuasan Pengguna terhadap Manfaat Bersih sebesar 3.515 lebih besar dari t-tabel 1,64 $(3,515>1,64)$ dan Original Sample (O) sebesar positif 0,520 maka dapat disimpulkan bahwa kepuasan pengguna berpengaruh positif terhadap manfaat bersih. Hal ini juga sejalan dengan penelitian Hudin dan Riana (2016) yang menyatakan bahwa Kepuasan Pengguna berpengaruh terhadap Manfaat Bersih.

Kepuasan Pengguna. Penggunaan berpengaruh positif trhadap Kepuasan Pengguna, hal ini berarti apabila jika Penggunaan semakin meningkat maka Kepuasan Pengguna semakin meningkat pula. Penggunaan berpengaruh positif terhhadap Manfaat Bersih. Kepuasan Pengguna berpengaruh positif terhadap Manfaat Bersih, hal ini berarti apabila jika Kepuasan Pengguna semakin meningkat maka manfaat bersih semakin meningkat pula. Untuk penelitian selanjutnya, hasil penelitian ini dapat digunakan sebagai kajian pustaka dalam rangka melakukan penelitian sejenis dengan cara menambah sampel penelitian serta merekontruksi model penelitian dengan variabel lain sehingga hasil penelitain sesuai dengan keadaan sebenarnya.

Parasuraman, A. Valerie, 2001. (Diterjemahkan oleh Sutanto) Delivering Quality Service. The Free Press, New York.

PERMENDAGRI. PENGELOLAAN KEUANGAN DESA (2014). Jakarta. Retrieved from www.keuangandesa.com Sugiono. (2016). Metode Penelitian Pendidikan Pendekatan Kuantitatif, Kualitatif, dan $R \& D$. (Alfabeta, Ed.). Bandung

Wisudiawan, G. A. A. (2015). Analisis faktor kesuksesan sistem informasi menggunakan model delone and mclean. Jurnal Ilmiah Teknologi Informasi Terapan.

Yasa, I. W. E. S., \& Ariyanto, D. (2017). Analisis Kesuksesan Sistem Informasi Manajemen Daerah Dengan Mengadopsi Model Delone \& Mclean. E_Jurnal Akuntansi, 18(3), 2505-2533.

DeLone, W. H., \& McLean, E. R. (2003). The DeLone and McLean model of information systems success: A tenyear update. Journal of Management Information Systems. https://doi.org/10.1080/07421222.2003.11045748 
Analisis Faktor Kesuksesan Implementasi Aplikasi Sistem Keuangan Desa (Siskeudes) Dengan Menggunakan Model Kesuksesan Sistem Teknologi Informasi Diperbarui Oleh Delone Dan Mclean Di Kabupaten Gianyar

Khairrunnisa, U., \& Yunanto, M. (2017). PENGARUH KUALITAS SISTEM TERHADAP KEPUASAN PENGGUNA DAN MANFAAT BERSIH PADA IMPLEMENTASI E-FAKTUR: VALIDASI MODEL KESUKSESAN SISTEM INFORMASI DELONE DAN MCLEAN. Jurnal Ilmiah Ekonomi Bisnis. https://doi.org/10.35760/eb.

Rio Jumardi, Eko Nugroho, I. H. (2015). Analisis Kesuksesan Implementasi Sistem Informasi Skripsi pada Program Studi Teknik Informatika Universitas Pembangunan Nasional " Veteran " Yogyakarta. Jurnal Inovasi Dan Kewirausahaan, ISSN 1907-5022, 7-13.

Wahyuni, T. (2011). Uji Empiris Model Delone Dan Mclean Terhadap Kesuksesan Sistem Informasi Manajemen Daerah (SIMDA). Jurnal BPPK. 